\section{RIVER RESEARCH IN EAST AFRICA} By D. VERNON D. van SOMEREN, M.B.E.

$\mathrm{A}$ $N$ important step forward in the conservation and development of the river fisheries in East Africa was taken on September 11, when the Governor of Kenya Culony, His Excellency Sir Philip Mitchell, formally opened the River Research and Develop. ment Contre near Nyeri Station in Kenya, in the presence of many people connected with fish and fishery problems.

Financed by grants from the Kenya Government and the Development and Reconstruction Authority of the Colony, this Centre has been built by the Kenya Game Department under the direction of the fish warden, Mr. Hugh Copley. The Centre consists of a research laboratory, a trout hatchery, and an administration centre situated on the banks of the Upper Sagana River, on the lower slopes of Mount Kenya. The staff at present consists of one biologist (Dr. V. D. van Someren), one assistant fish warden (Major D. F. Smith) and a hatchery superintendent, the whole being administered by the head offices of the Game Department in Nairobi.

The function of the Centre is twofold, namely, river fishery research and practical fish breerling, neither of which has hitherto been investigated scientifically in the Colony. On the fishery research side, the first object is to provide a scientific back. ground for developing the trout fishery resources of East Africa. Both rainbow and brown trout were first introduced to Kenya about forty years ago, and since then the trout fisheries have been developed as a considerable sporting and tourist asset, most of the rivers now being stocked. The practical management of these fisheries has so far been run successfully on an ad hoc basis; but it has been felt for some time now that any further advance must be based on scientific research into river productivity and fishery management. Deterioration in growth-rate of trout, for example, has taken place in several of the rivers since their initial stocking, and this is but one aspect of the problem which is being investigated. After. wards. such research will be carried further to investigate fully the indigenous fisheries of the lower reaches of the rivers where trout will not live. In some rivers there exist native fisheries for Tilapia, Barbus, eels, catfish and the like, and research would undoubtedly improve the yield of such food fish for the African population.

Other research aspects of the Centre's work include the large-scale systematic rearing of aquatic insect nymphs and larvæ, since the majority of such in East African rivers are as yet unnamed. The food productivity per unit area of river bottom is being investigated in relation to the population of fish. The food and growth-rate of the fish themselves are also under study, and the rivers present many interesting ecological features in the distribution of fish and other aquatic life, since they may rise at an altitude up to $14,000 \mathrm{ft}$. and finally discharge at sea-level.

It is the intention that this Centre should work in close co-operation with the Wray Castle Laboratory of the Freshwater Biological Association in England, and to this end Dr. Winifred Frost, of the Wray Laboratory, has already spent six months working at the Centre on East African river eels and trout fisheries. Close liaison will also be maintained with the East Africa Inland Fishery Research Institute at Jinja in Uganda, now in course of construction, and it is possible that amalgamation of the two may later take place, with the added advantage of staff interchange.

On the educational side, short vacation courses in freshwater biology will be held for pupils of the Kenya secondary schools and probably also for Afriean biology students from Makerere College in Uganda. The first vacation course for girls of the Kenya High School has already taken place.

The laboratory has accommodation for visiting scientific workers, and it is hoped that students from overseas will take advantage of the facilities to study, not only fishery problems, but also other aspects of the biological, physical and chemical phenomena in East African rivers. Guest-house accommodation has been provided for such visitors at the Centre.

Practical trout breeding will go hand-in-hand with research, the hatchery being designed to accommodate up to 150,000 ova. This is the first such hatchery to be built in East Africa, and will serve the three East African territories and farther afield if required. Some of the first batch of fry reared have already been sent to the Sudan. Biological work in connexion with the proposed Government fish culture farm for indigenous fish will also be undertaken.

The biology, breeding and growth of fish and other aquatic life in these high-altitude regions, with a sub-tropical climate and little variation in seasons, present many interesting problems compared with temperate climates. Over a period of years, the results of research should be not only of practical economic importance but also of fundamental biological interest.

\section{ROAD RESEARCH IN SCOTLAND}

A $\mathrm{S}$ an initial step in the founding of a Scottish A branch at East Kilbride, near Glasgow, of the Ruad Research Laboratory, were a conference and exhibition held at the Royal Technical College, Glasgow, on September 24, under the auspices of the Road Research Organisation of the Department of Scientific and Industrial Research in association with the Institution of Civil Engineers (Glasgow and District Association), the Institution of Municipal Engineers (Scottish Branch), the County Surveyors' Society (Scottish Branch) and the Scottish Accident Pre. vention Council. Sir Patrick Dollan presided over the conference; the chair at the morning session was taken by Colonel T. U. Wilson, county surveyor of Lanarkshire, and at the afternoon session by $\mathrm{Mr}$. C. S. Sherriff, chairman of the Scottish Accident Prevention Council.

The conference and exhibition were arranged to make the work of the Road Research Organisation better known to Scottish road engineers, and to obtain from them further information on problems and difficulties peculiar to Scotland. In his opening remarks in the morning session, which was devoted to road materials and methods of road construction, the director of road research, Dr. W. H. Glanville, stressed the need for developing sympathetic understanding and co-operation between the practising engineers, who apply the results of research, and the scientific workers in the laboratory: he explained that the new laboratory would begin as a small organisation; but he hoped it would grow as the problems to be attacked were disclosed and as its 